Journal Universitas Muhammadiyah Gresik Engineering, Social Science, and Health International Conference (UMGESHIC)

UMGCINMATIC : $1^{\text {st }}$ Rethinking Education during Covid-19 Era: Challange and Innovation

\title{
THE INFLUENCE OF BRAND IMAGE ON REPURCHASE INTENTION ON CEMENT PRODUCTS IN STORE $X$
}

\author{
Author \\ Rafida Zunaini, Asri Rejeki, Ima fitri sholichah \\ Faculty of Psychology, University of Muhammadiyah Gresik \\ rafida.zunaini@gmail.com, asrirejeki@umg.ac.id,ima_fitri@umg.ac.id
}

\begin{abstract}
Consumers are used to buying cement brands that they are used to buying. Consumers have their own perception of the brand. Consumers who are familiar with the cement they have used will buy this brand again. This study aims to see the effect of brand image on repurchase intention on cement products at shop $\mathrm{x}$. This research is quantitative research. The 50 participants were collected by incidental sampling. Data collected through questionnaires The reliability test was carried out by calculating the Cronbach Alpha reliability correlation. The data analysis technique used a simple linear regression technique. The results of the study indicate that there is a significant positive effect between the brand image and repurchase intention variables, which means that the more positive the brand image, the higher the repurchase intention. This research is expected to enrich the knowledge of readers about the topic of brand image, especially the influence of brand image on repurchase intention in students of the Faculty of Engineering, University of Muhammadiyah Gresik. In addition, the results of the existing research are expected to be a reference for further research. This study uses an incidental sampling technique so that it cannot be ascertained that the representatives of the subjects from all study programs are not certain. It is hoped that future researchers will use subjects from all study programs so that research results can be generalized.
\end{abstract}

Keywords: repurchase, brand image 


\section{INTRODUCTION}

The rapid development of today's era presents its own challenges for business people, this is because, in this technological era, there are many new products that are flooding the market. The rapid development of the business world has led to increased business competition, especially for manufacturers that produce similar products. Therefore, a qualified strategy is needed so that these products can compete and win market share.

Currently, the construction of houses and infrastructure development is being carried out, both from the middle and upper classes. As we know, the government runs an infrastructure program. Developments that have occurred during project completion in Indonesia include the completion of national strategic projects that have been implemented since 2020, including the construction of 48 dams, construction of $406 \mathrm{~km}$ toll roads, 25,000 hectares of irrigation, 2,012 lt/s SPAM, 9,705 apartments, and rehabilitation of schools/colleges/sports buildings. (Patriella, nd) cement is one of the adhesives for infrastructure development. The circulation of cement brands that increases every year makes the competition even tougher. The old cement brands have made changes in quality and durability so they don't lag behind the newest cement brands.

Consumers are used to buying cement brands that they are used to buying because cement has been present in the industrial market for a long time. Consumers have their own perception of the brand. Consumers who are familiar with the cement they have used will buy the brand again. Consumers will continue to compare one cement with another. Many consumers will re-purchase with cement they have used before, even though there are new cement brands. consumers plan to repurchase cement when they consider building or repairing a house. It is not uncommon for consumers to ask about various brands of cement sold in a store. Consumers will ask about the quality and advantages of each brand of cement but in the end, consumers still buy cement with the cement brand they usually use.

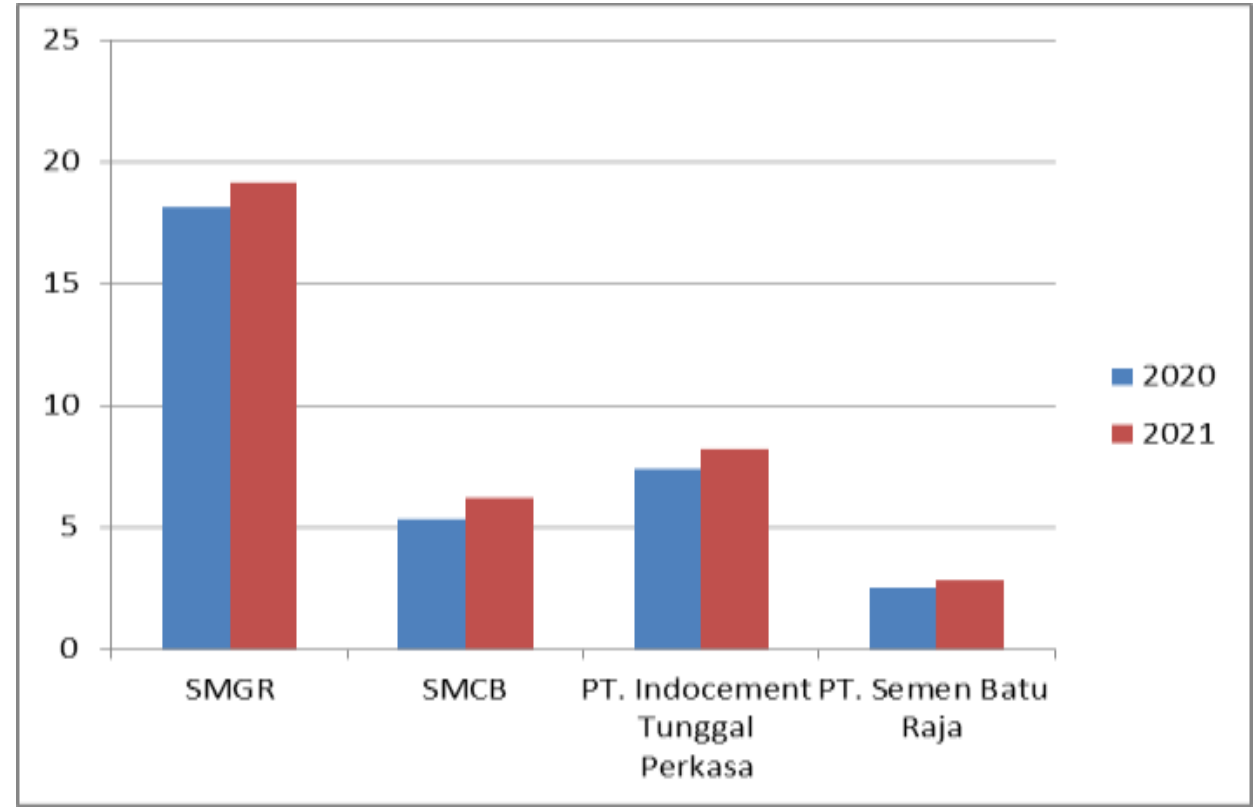

Figure 1. PT Semen Indonesia Tbk ( $\underline{\text { SMGR }) ~ m a n a g e d ~ t o ~ r e c o r d ~ s a l e s ~ v o l u m e ~(i n c l u d i n g ~ d o m e s t i c ~}$ clinker sales). 


\section{UMGCINMATIC : $1^{\text {st }}$ Rethinking Education during Covid-19 Era: Challange and Innovation}

Volume 1 No 2

This number increased by $5.7 \%$ from sales in the same period of 18.11 million tons. PT Solusi Bangun Indonesia Tbk ( $\underline{\mathrm{SMCB}}$ ) also recorded a brilliant performance throughout the first half of 2021. Until the end of June 2021, the cement manufacturer from the Dynamix brand recorded a sales volume of 6.22 million tons of cement. This figure increased by $17.73 \%$ from the realization of sales in the same period the previous year of 5.29 million tons. PT Indocement Tunggal Prakarsa Tbk (INTP) also did not want to lose. INTP managed to record a total sales volume of 8.19 million tons during the first six months of 2021 . This figure rose $11.3 \%$ from sales realization in the same period the previous year which was only 7.36 million tons. PT Semen Baturaja Tbk ( $\underline{\text { SMBR }})$ also recorded a good performance throughout semester I-2021. Semen Baturaja Corporate Secretary Doddy Irwan said the realization of SMBR sales grew by $14 \%$ compared to the same period in 2020. (Suryahadi, 2021)

Brand Image According to the American Marketing Association (AMA) Kotler (2003), a brand refers to a name, term, logo, symbol or design or a guideline of these things, which is intended as a product or service that is produced or provided. seller or group of sellers and differentiate them from the goods or services offered by competitors. Today, the brand has become a very valuable asset for the company. Companies that have a strong brand tend to more easily meet the needs and desires in accordance with consumer perceptions.

Research conducted by (Sari Lestia 2017), the results show that $69.2 \%$ of repurchase intention can be explained by the brand image variable. Research conducted by (Ain 2015), has research results that show brand image has an effect on repurchase intention.

\section{METHODS}

This study uses a quantitative approach. The type used in this study is a correlation. Correlation is an analysis used to determine whether there is a relationship between two variables (Azwar, 2014). The variables in this study were repurchase intention (dependent variable), brand image (independent variable). The research subjects were 50 consumers. Population and Sampling Techniques in this study were Non-Probability sampling, namely incidental sampling, which means determining the sample based on chance, i.e., who was met by chance by the researcher and deemed fit with the research criteria, then it can be used as a sample (Sugiyono, 2019: 67). The measuring instrument used uses a scaleZeithaml et al (1996) to reveal repurchase buying Behavioral-Intention Battery which consists of 13 items (which later modified into 18 items) and brand image is built from the theory of Keller (2003). The reliability test was carried out by calculating the Cronbach Alpha reliability correlation which one with the help of the program computer JASP 15.0 for windows

\section{RESULT AND DISCUSSION}

a. Research Data Reliability

The repurchase intention scale shows a Crobanbach's Alpha coefficient of 0.56. Meanwhile, the brand image scale shows the Crobanbach's Alpha coefficient of 0.63. Based on the results of the reliability coefficient, the reliability of the repurchase intention scale data and the brand image scale data can be said to be good (Suryabrata, 2012: 28).

$b$. Description of Research Data This research was conducted on 50 consumers who made a purchase of cement at shop X. Research data collection takes place in September 2021. 
c. Hypothesis testing, the results of data analysis using simple linear regression analysis. Researchers tested the regression between variables with the help of the JASP 0.15 For Windows application.

Table 1. ANOVA Test Results

\begin{tabular}{ll}
\hline $\mathrm{F}$ & $\mathrm{P}$ \\
\hline 25,855 & $<.001$ \\
\hline
\end{tabular}

The results of the $F$ test analysis showed that the $F$ value was 25,855 with a significance of $0.001<0.05$ because the sign was smaller than 0.05 , Ha accepted that there was an influence of brand image on repurchase intention. Regression can be used to predict the brand image variable that influences repurchase intention. , because the probability is smaller than 0.05 , the regression model can be used in predicting the academic self-efficacy variable that affects academic burnout (Priyatno, 2014:142).

Table 2. Regression Test Results

\begin{tabular}{ll}
\hline Variable & $\mathrm{R} 2$ \\
\hline $\begin{array}{l}\text { Brand image and repurchase } \\
\text { intention }\end{array}$ & 0.350 \\
\hline
\end{tabular}

The value of $\mathrm{R}$ Square or the coefficient of determination used to determine the percentage of the influence of the independent variable (predictor) on changes in the dependent variable is 0.350 which comes from the square of the correlation value of 0.592 . The $R$ Square value of 0.350 means that the magnitude of the influence of the independent variable (brand image) on changes in the dependent variable (repurchase intention) is $35 \%$, while the remaining $65 \%$ is influenced by other variables not examined. The following are the results of the regression test.

Table 3. Regression Coefficient Test Results

\begin{tabular}{lll}
\hline $\mathrm{t}$ & $\mathrm{B}$ & Std. Error \\
\hline 5.085 & 28,646 & 3,464 \\
& 0.227 & 0.045 \\
\hline
\end{tabular}

It can be seen that the coefficient value is 28.646 and the brand image value is 0.227. Thus, these results show the equation of the regression line between brand image and repurchase intention. 


\section{CONCLUSIONS}

The results of the regression coefficient test show that the sig column or the significance of the independent variables and constants have a significance level below 0.05 then Ha is accepted and Ho is rejected. This means that there is are the effect of brand image on repurchase intention on cement products at shop X. The results of the R Square test or the coefficient of determination show a value of 0.35. This shows that the influence of the independent variable (brand image) on the dependent variable of repurchase intention is $31 \%$, while the remaining $65 \%$ is influenced by other variables not examined. Further research suggestions

In collecting research data, further researchers are expected to expand the population and number of samples so that the results of the research carried out are better. Further researchers who are interested in researching repurchase intention can examine other constructs or other factors that can affect repurchase intention. Mentioned (e.g. other factors affecting the other 65\%)

\section{REFERENCES}

[1]Ain, N. (2015). The Influence of Brand Image Through Consumer Attitudes Towards Repurchase Intentions On Zoya Muslim Clothing Products In Surabaya. Jest, 2(7).

[2]Ardhanari, M. (2008). Customer Satisfaction Effect on Brand Preference and Repurchase Intention Private Brand. Customer Satisfaction Effect on Brand... (Margaretha Ardhani) Journal of Economics and Business Research, 588(2), 58-69.

[3]Han, ES, \& Goleman, Daniel; Boyatzis, Richard; Mckee, A. (2019). $\square$ No Title No Title. Journal Of Chemical Information And Modeling, 53(9), 1689-1699.

[4]Hellier, PK, Geursen, GM, Carr, RA, \& Rickard, JA (2003). Customer Repurchase Intention. $\begin{array}{llll}\text { European Journal } \quad \text { Of } & \text { Marketing, }\end{array}$ Https://Doi.Org/10.1108/03090560310495456

[5]Hidayah, N., \& Aniarwati, AL (2018). Influence of Perceived Quality on Repurchase Intention with Satisfaction as an Intervening Variable (Study on Sosro Bottle Tea Customers in East Surabaya). Journal of Management Science, 6(1), 1.

[6]Kotler, P., \& Keller, KL (2016). Marketing Management Global Edition (Vol. 15E). Https://Doi.Org/10.1080/08911760903022556

[7]Manopo, KYW, \& Widayanto. (2019). EFFECT OF E-SERVICE QUALITY AND BRAND IMAGE ON REPURCHASE INTENTION THROUGH E-SATISFACTION (Case Study on FISIP UNDIP Students Who Have Made Purchases at OLX.Co.Id). Journal Of Chemical Information And Modeling, 53(9), 1-19.

[8]Mendrika, SG (2019). INFLUENCE OF BRAND IMAGE ON ORIFLAME REPURCHASING INTEREST Case Study: Student of Campus 1, University of Sanata Dharma. Journal Of Chemical Information And Modeling, 53(9), 1689-1699.

[9]Muhammad Sabbir Rahman; Osman Mohamad; Fadi Abdel Muniem Abdelfattah; Nusrat Aziz. (2014). Factor Determining Customers' Repurchase Intention Of Healthcare Insurance Products. Australian Academy Of Business And Social Sciences Conference 2014, 2014. Http://Www.Aabss.Org.Au

[10]State, A. . NDE, Arifin, Z., \& Nuralam, IP (2018). The Effect of Product Quality and Brand Image on Buying Interest (Survey of Buyers at Starbucks Outlets in Surabaya City). Journal of Business 
Administration (JAB), 61(2), 202-209.

[11]Peter, PJ, \& Olson, JC (2012). Consumer Behavior Marketing.

[12]Priyatno, Duwi. 2014. SPSS 22 Practical Data Processing. Yogyakarta: CV Andi Offset.

[13]Ramadhan, AG, \& Santosa, SB (2017). Analysis of the Effect of Product Quality, Service Quality, and Brand Image on Repurchase Interest in Nike Running Shoes in Semarang through Customer Satisfaction as an Intervening Variable. Diponegoro Journal Of Management, 6(1), 1-12. Https://Ejournal3.Undip.Ac.Id/Index.Php/Djom/Article/View/17525/16774

[14]Regi Miranda, N. (2020). The Influence of Service Quality, Trust, and Brand Image on Repurchase Intentions for Simpati Star PO Transportation Services in Banda Aceh City. Scientific Journal of Management Economics Students, 11(1), 61-82.

[15]Saununu, SJ (2019). ANALYSIS OF THE INFLUENCE OF ELECTRONIC TRANSMISSIONS. 7, 51-58.

[16]Setyorini, R., \& Nugraha, RP (2016). The Effect Of Trust Towards Online Repurchase Intention With Perceived Usefulness As An Intervening Variable : A Study On KASKUS Marketplace Customers. The Asian Journal Of Technology Management, 9(1), 1-7.

[17]Sugiyono. (2018). Quantitative, Qualitative, and R\&D Research Methods. Bandung: Alphabeta.

[18]Sugiyono. (2017). Quantitative Research Methods and R\&D. Bandung: Alphabeta.

[19]Sugiyono. (2019). Quantitative Research Methods and R\&D. Bandung: Alphabeta.

[20]Wibowo, SE, Ruswanti, E., \& Januarko, U. (2013). The Influence of Service Quality Perceptions on Repurchase Intentions. Yogyakarta Gramedia Bookstore Journal of Economics, 4(1), 56-64.

[21]Wijayasari, N., \& Mahfudz. (2018). The Influence of Brand Image, Quality, Perception of Price and Product Variations on Consumers' Purchase Interest of Sarong Gajah Sitting in Pekalongan Regency. Diponegoro Journal Of Management, 7(2), 1-9. Http://EjournalS1.Undip.Ac.Id/Index.Php/Dbr

[22]Wijaya, R., Farida, N., \& Andriyansah. (2018). Determinants Of Repurchase Intentions At Online Stores In Indonesia. International Journal Of E-Business Research, 14(3), 95-111. Https://Doi.Org/10.4018/IJEBR.2018070106

[23]Wiguna, PY, \& Santika, W. (2020). The Role of Brand Image in Mediating the Effect of Sponsorship on Repurchase Intentions. Management, 9(1), 199-217.

[24]Wijaya, RH, \& Astuti, SR (2018). The Effect Of Trust And Brand Image To Repurchase Intention In Online Shopping. International Conference on Economics, Business and Economic Education.

[25]Wilson, N. (2019). The Impact Of Perceived Usefulness And Perceived Ease-Of-Use Toward Repurchase Intention In The Indonesian E-Commerce Industry. Indonesian Journal of Management, 19(3), 241. Https://Doi.Org/10.25124/Jmi.V19i3.2412 